\title{
STABILITAS PELAT ORTHOTROPIK AKIBAT BEBAN LEDAKAN FRIEDLANDER DAN BEBAN IN-PLANE
}

\author{
Levina Lammirta ${ }^{1}$, Sofia Wangsadinata Alisjahbana ${ }^{2}$ \\ ${ }^{1}$ Magister Teknik Sipil, Universitas Tarumanagara, Jakarta \\ Email:levina.lammirta@gmail.com \\ ${ }^{2}$ Universitas Bakrie, Jakarta \\ Email: sofia.wangsadinata@gmail.com
}

Masuk: 04-07-2021, revisi: 06-10-2021, diterima untuk diterbitkan: 28-10-2021

\begin{abstract}
ABSTRAK
Perilaku pelat akibat adanya beban statik dan beban dinamik perlu menjadi pertimbangan pada saat mendesain pelat. Salah satu contoh beban dinamik adalah beban ledakan setempat (Friedlander). Beban dinamik dapat memberikan respon yang beragam pada pelat. Penelitian ini membahas mengenai pelat orthotropik di atas pondasi Pasternak dengan kondisi jepit dengan beban in-plane dan beban ledakan setempat (Friedlander). Beban ledakan setempat (Friedlander) dianalisis dalam tiga fase yaitu fase positif, fase negatif, dan fase getaran bebas. Penelitian dilakukan untuk mengetahui beban tekuk kritis akibat variasi koefisien pondasi Pasternak yaitu koefisien pegas dan koefisien geser. Respons sistem yang diamati adalah lendutan dan momen yang dihasilkan akibat adanya variasi terhadap parameter pondasi Pasternak, besaran beban kritis, posisi beban, kedalaman tanah, dan durasi fase positif beban. Analisis dilakukan dengan Modified Bolotin Method untuk mendapatkan frekuensi alami dan ragam getar yang terjadi. Hasil analisis akan dibandingkan dalam bentuk grafik dan tabel. Berdasarkan hasil penelitian, batas maksimum beban tekan kritis adalah $77 \%$ dari beban kritis yang digunakan. Koefisien tanah yang semakin besar akan membuat lendutan yang terjadi semakin besar. Posisi beban yang mendekati tengah bentang akan membuat lendutan semakin besar. Lendutan yang terjadi semakin besar apabila kedalaman tanah semakin meningkat dan durasi beban ledakan yang semakin lama. Apabila semakin besar tebal pelat maka lendutan yang terjadi semakin kecil.
\end{abstract}

Kata kunci: Modified Bolotin Method; beban ledakan setempat Friedlander; lendutan pelat; beban kritis, pondasi Pasternak

\begin{abstract}
Slab behavior due to static and dynamic load needs to be considered when designing a slab. Friedlander is one of the examples of dynamic loads. This dynamic load can give different responses on slab. This research discusses about orthotropic plate on Pasternak foundation with fixed boundary condition and in-plane and Friedlander load. Three phases on Friedlander load are positive phase, negative phase, and free vibration phase. This research is conducted to find out critical buckling load due to variation of Pasternak foundation parameters which is spring coefficient and shear coefficient. The system responses are deflection and bending moment due to variation of Pasternak foundation parameter, critical loading, position of loads, depth of soil, and duration of positive phase. Analysis is carried out using Modified Bolotin Method to obtain natural frequencies and mode shape of the system. Result of this research are displayed in graphics and tables. Based on the results, the maximum limit of the critical compressive load is $77 \%$ of the critical load used. The increasing of soil coefficient, the greater the deflection that occurs. The position of the load that is close to the center of the span will make the deflection even greater. The deflection that occurs is greater when the depth of the soil increases and the duration of the blast load is getting longer. The greater the thickness of the plate, the smaller the deflection.
\end{abstract}

Keywords : Modified Bolotin Method; Friedlander blast load; plate deflection; critical load; Pasternak Foundation 


\section{PENDAHULUAN}

Pelat merupakan elemen struktur dua dimensi yang lurus, datar, dimana salah satu dimensinya disebut sebagai ketebalan pelat $h$ yang dimana memiliki ukuran yang lebih kecil dibandingkan dengan dimensi lainnya (Szilard, Rudolph, 2004). Dalam perencanaan sebuah pelat, terlebih dahulu ditentukan jenis pelat yang akan digunakan dengan mempertimbangkan kebutuhannya. Setelah jenis pelat ditentukan barulah pelat tersebut diberi pembebanan berdasarkan fungsi bangunan. Beban in-plane merupakan salah satu beban yang berkaitan dengan pelat. Beban inplane merupakan beban yang bekerja pada sisi pelat. Pada umumnya pelat hanya diberikan beban hidup, beban mati, beban mati dan beban gempa. Padahal selain beban tersebut, terdapat beban dinamik yang perlu diperhitungkan karena menjadi faktor yang penting dalam sebuah perencanaan. Contoh beban dinamik adalah beban mesin, beban kendaraan bergerak, beban ledakan dan lain-lain.

Menurut Ngo et al. (2007) sebuah ledakan didefinisikan sebagai pelepasan energi yang terjadi secara tiba-tiba, cepat, dan dalam skala yang besar. Pelepasan energi secara tiba-tiba menghasilkan gelombang tekanan dalam medium sekitarnya, yang dikenal sebagai gelombang kejut yang menghasilkan tekanan (Moon, 2009). Banyak hal yang mempengaruhi sebuah ledakan yaitu jenis peledak, jarak peledak, durasi ledakan, besar ledakan, dll.

Pelat lantai pada lantai dasar sebuah bangunan akan terhubung dengan tanah. Pemodelan tanah di bawah pelat lantai juga dapat dilakukan dengan menggunakan pondasi Pasternak. Pondasi Pasternak memiliki 2 buah lapisan yaitu lapisan geser dan lapisan pegas. Pondasi ini lebih mendekati kondisi tanah yang sebenarnya.

Beban statik dan beban dinamik yang terjadi harus diperhitungkan akibatnya terhadap pelat lantai. Terdapat dua hal yang berpengaruh dalam analisis pelat yaitu kekakuan dan massa. Hal tersebut dinyatakan dalam eigenvalue yang merupakan frekuensi alami dan eigen vector yang merupakan ragam getar. Untuk itu digunakan Modified Bolotin Method yang dianggap cocok untuk mencari nilai tersebut.

Solusi dari persamaan gerak tersebut terdiri dari solusi homogen (free vibration response) dan solusi partikuler (forced vibration response). Solusi homogen dianalisa dengan persamaan diferensial undamped dan memiliki hubungan tertentu dengan frekuensi alami sistem. Diasumsikan boundary condition yang digunakan adalah sendi atau terletak sederhana sehingga tidak terjadi translasi vertikal dan momen lentur. Selanjutnya menentukan trial function yang memenuhi boundary condition untuk mendapatkan eigenvalue.

Didasarkan pada latar belakang di atas, maka perlu dilakukan penelitian mengenai stabilitas pelat lantai terhadap beban in-plane dan beban setempat (friendlander) menggunakan pemodelan Pasternak.

\section{PERSAMAAN KESEIMBANGAN GERAK PELAT}

Penelitian ini akan membahas mengenai lendutan dan tegangan yang terjadi pada pelat persegi empat. Perletakan pelat akan diasumsikan terjepit sempurna dengan beban yang digunakan adalah kombinasi beban in-plane dan beban ledakan Friedlander. Beban In-plane akan dikombinasikan antara arah $\mathrm{x}$ dan y sedangkan beban ledakan Friedlander sudah ditentukan besar dan letaknya. Pelat yang akan diteliti merupakan pelat lantai dasar dengan pondasi Pasternak dimana terdapat sebuah lapisan geser dan sebuah lapisan pegas. Penelitian ini dilakukan untuk memperoleh tegangan dan lendutan yang terjadi pada pelat Orthotropik.

Persamaan keseimbangan gerak struktur pelat Orthotropik akibat beban In-plane dan beban ledakan Friedlander pada pondasi Pasternak adalah sebagai berikut: 
$D_{x} \frac{\partial^{4} w}{\partial x^{4}}+2 B \frac{\partial^{4} w}{\partial x^{2} \partial y^{2}}+D_{y} \frac{\partial^{4} w}{\partial y^{4}}+\rho h \frac{\partial^{2} w}{\partial t^{2}}+\xi h \frac{\partial w}{\partial t}+k_{f} w-G_{s}\left(\frac{\partial^{2} w}{\partial x^{2}}+\frac{\partial^{2} w}{\partial y^{2}}\right)+N_{x}\left(\frac{\partial^{2} w}{\partial x^{2}}\right)+$

$N_{y}\left(\frac{\partial^{2} w}{\partial y^{2}}\right)=p_{z}(x, y, t)$

Pada persamaan di atas, w merupakan fungsi lendutan yang merupakan gabungan antara fungsi posisi dan fungsi waktu yang dinyatakan dalam bentuk w(x,y,t). $\mathrm{D}_{\mathrm{x}}$ dan $\mathrm{D}_{\mathrm{y}}$ merupakan kekakuan lentur arah $\mathrm{x}$ dan, $\rho$ merupakan massa jenis, $\mathrm{k}_{\mathrm{f}}$ merupakan koefisien pegas pondasi Pasternak, $\mathrm{G}_{\mathrm{s}}$ merupakan koefisien geser pondasi Pasternak, $\mathrm{N}_{\mathrm{x}}$ dan $\mathrm{N}_{\mathrm{y}}$ beban in-plane dalam arah $\mathrm{x}$ dan $\mathrm{y}$. Pada penelitian ini menggunakan pelat Orthotropik dimana kekakuan pelat berbeda di setiap arahnya.

\section{ANALISIS FREKUENSI ALAMI DAN BEBAN KRITIS}

Solusi persamaan gerak pelat terdiri dari solusi homogen dan solusi partikular. Solusi homogen diperoleh dengan menyelesaikan persamaan keseimbangan gerak pelat dengan beban $\operatorname{Pz}(\mathrm{x}, \mathrm{y}, \mathrm{t})=0$. Sementara solusi partikular diperoleh dengan penyelesaian persamaan gerak pelat dengan beban transversal dinamis $\operatorname{Pz}(\mathrm{x}, \mathrm{y}, \mathrm{t}) \neq 0$.

Beban tekan in-plane merupakan beban yang berada sejajar dengan ketebalan pelat. Beban ini menyebabkan terjadinya tekuk (buckling) pada pelat, sehingga terjadi ketidaksatabilan elastis. Apabila beban in-plane yang bekerja melebihi batas beban kritis pada pelat maka akan terjadi tekuk secara tiba-tiba. Besar beban in-plane tidak didasarkan pada beban transversal (Timoshenko, 1955). Nilai beban in-plane arah $\mathrm{x}$, koefisien pegas, dan koefisien dinyatakan seperti di bawah ini.

$N_{x}=\frac{N_{0} b^{2}}{\Pi^{2} \sqrt{D_{x} D_{y}}}$

$k_{f}=\frac{k b^{2}}{\Pi^{4} \sqrt{D_{x} D_{y}}}$

$G_{s}=\frac{G b^{2}}{\Pi^{2} \sqrt{D_{x} D_{y}}}$

Apabila persamaan (2), (3), (4) dimasukan ke dalam persamaan (1) maka akan didapatkan persamaan $\mathrm{N}$ kritis sebagai berikut:

$N_{c r}=\frac{16 b^{4} D_{x} \sqrt{D_{x} D_{y}} m^{4} \Pi^{8}+4 a^{2} b^{2} m^{2} \Pi^{4}\left(b^{4} G_{s}+8 B \sqrt{D_{x} D_{y}} \llbracket n^{2} \Pi^{4}\right)+a^{4}\left(b^{8} k \rrbracket_{f}+16 D_{y} \sqrt{D_{x} D_{y}} n^{4} \Pi^{8}-b^{6} G_{s} \Pi^{2} y\right)}{\Pi^{2} \sqrt{D_{x} D_{y}}}$

\section{Masalah Pelat Tipe Levy}

Masalah pelat tipe Levy dapat dikategorikan menjadi dua, yaitu masalah tipe Levy pertama (auxiliary I) dan masalah tipe Levy kedua (auxiliary II). Masalah tipe Levy pertama memberikan solusi fungsi posisi $\mathrm{X}(\mathrm{x})$ di arah $\mathrm{x}$ sedangkan di arah y dibiarkan mengikuti gerak harmonis. Masalah tipe Levy kedua memberikan solusi fungsi posisi $\mathrm{Y}(\mathrm{y})$ di arah y sedangkan di arah $\mathrm{x}$ dibiarkan mengikuti gerak harmonis. Dari masalah auxiliary tersebut didapatkan nilai 'p' dan 'q' yang kemudian dapat digunakan untuk memperoleh besarnya frekuensi alami.

Fungsi posisi auxiliary I dimasukkan ke dalam empat syarat batas, sehingga fungsi posisi untuk auxiliary pertama pada arah $\mathrm{x}$ adalah: 


$$
\begin{aligned}
& X(x)=\cosh \left(\frac{\beta \pi x}{a b}\right)+\frac{b p\left(\cos [p \pi]-\cosh \left[\frac{\pi \beta}{b}\right]\right) \sinh \left(\frac{\beta \pi x}{a b}\right)}{-\beta \sin [p \pi]+b p \sinh \left[\frac{\pi \beta}{b}\right]} \sinh \left(\frac{\beta \pi x}{a b}\right)-\cos \left(\frac{p \pi x}{a}\right)+ \\
& \frac{\beta\left(\operatorname{Cos}[p \pi]-\operatorname{Cosh}\left[\frac{\pi \beta}{b}\right]\right) \operatorname{Sin}\left[\frac{p \pi x}{a}\right]}{\beta \operatorname{Sin}[p \pi]-b p \operatorname{Sinh}\left[\frac{\pi \beta}{b}\right]} \sin \left(\frac{p \pi x}{a}\right)
\end{aligned}
$$

Fungsi posisi auxiliary II di masukkan ke dalam empat syarat batas, sehingga fungsi posisi untuk auxiliary kedua pada arah y adalah:

$$
\begin{aligned}
& Y(y)=\operatorname{Cosh}\left[\frac{\pi y \theta}{a b}\right]+\frac{a q\left(\operatorname{Cos}[\pi q]-\operatorname{Cosh}\left[\frac{\pi \theta}{a}\right]\right) \operatorname{Sinh}\left[\frac{\pi y \theta}{a b}\right]}{-\theta \operatorname{Sin}[\pi q]+a q \operatorname{Sinh}\left[\frac{\pi \theta}{a}\right]} \operatorname{Sinh}\left(\frac{\beta \pi x}{a b}\right)-\operatorname{Cos}\left[\frac{\pi q y}{b}\right]+ \\
& \frac{\theta\left(\operatorname{Cos}[\pi q]-\operatorname{Cosh}\left[\frac{\pi \theta}{a}\right]\right) \operatorname{Sin}\left[\frac{\pi q y}{b}\right]}{\theta \operatorname{Sin}[\pi q]-a q \operatorname{Sinh}\left[\frac{\pi \theta}{a}\right]} \operatorname{Sin}\left(\frac{p \pi x}{a}\right)
\end{aligned}
$$

\section{Solusi Homogen}

Solusi homogen, wH, adalah solusi untuk keadaan struktur yang tidak menerima eksitasi yang berupa beban melainkan karena adanya deformasi atau kecapatan awal (initial condition) yang menyebabkan akan terjadinya respons struktur. Dengan demikian solusi homogen, $\mathrm{wh}_{\mathrm{h}}$, struktur pelat dapat dinyatakan sebagai berikut:

$w_{h}=w(x, y, t)=\sum_{m-1}^{\infty} \sum_{n-1}^{\infty} W_{m n}(x, y) \cdot T_{m n}(t)$

$w_{h}=\sum_{m-1}^{\infty} \sum_{n-1}^{\infty}\left[X_{m n}(x) \cdot Y_{m n}(y)\right] \cdot e^{-\xi \omega_{p q} t}\left[a_{0} \cos \left[\omega_{D}\right] \mathrm{t}+b_{0} \sin \left[\omega_{D}\right] t\right]$

\section{Solusi Partikuler}

Sama halnya dengan solusi homogen, solusi partikuler dapat diperoleh dengan cara menggunakan metode pemisahan variabel. Koefisien-koefisien yang terdapat pada solusi homogen sesuai dengan persamaan (3.76) diekspansi sesuai dengan pengaruh beban luar (excitation forces) yang belum ada pada solusi homogen yang dapat dinyatakan sebagai:

$w_{p}=w(x, y, t)=\sum_{p=1}^{\infty} \sum_{q=1}^{\infty} X_{p q}(x) Y_{p q}(y) T_{p q}(t)$

Solusi partikular dari persamaan diferensial merupakan gabungan solusi spatial dan solusi partikular temporal sebagai berikut:

$$
\begin{aligned}
& w_{p}=\sum_{p=1}^{\infty} \sum_{q=1}^{\infty} X_{p q}(x) Y_{p q}(y) \\
& \int_{0}^{t}\left[\frac{P_{z}(x, y, t)}{\rho h Q_{p q}} \int_{x=0}^{a} X_{p q}(x) d x \int_{y=0}^{b} Y_{p q}(y) d y\left(\frac{e^{-\xi \omega_{p q} t}}{\omega_{p q} \sqrt{1-\xi^{2}}} \sin \left(\sqrt{1-\xi^{2}} \omega_{p q} \sqrt{t-\tau}\right)\right)\right] d \tau
\end{aligned}
$$

\section{Solusi Total}

Solusi total sistem dapat dinyatakan $\mathrm{w}(\mathrm{x}, \mathrm{y}, \mathrm{t})=\mathrm{X}(\mathrm{x})$. $\mathrm{Y}(\mathrm{y}) \cdot\left[\hat{T}(t)+T^{*}(t)\right]$, atau dapat dinyatakan juga sebagai $\mathrm{w}=\mathrm{w}_{\mathrm{h}}+\mathrm{w}_{\mathrm{p}}$ di mana $\mathrm{w}_{\mathrm{h}}$ adalah solusi homogen sesuai dengan persamaan (10) dan 
$\mathrm{W}_{\mathrm{p}}$ adalah solusi partikular sesuai dengan persamaan (11), yang secara lengkap dapat dinyatakan sebagai berikut:

$$
\begin{aligned}
& w(x, y, t)=\sum_{p=1}^{\infty} \sum_{q=1}^{\infty}\left[X_{p q}(x) Y_{p q}(y)\right] e^{-\xi \omega_{p q} t}\left(a_{0[p, q]} \cos \left[\sqrt{1-\xi^{2}} \omega_{p q}\right] t+\right. \\
& \left.b_{0[p, q]} \sin \left[\sqrt{1-\xi^{2}} \omega_{p q}\right] t\right)+ \\
& \sum_{p=1}^{\infty} \sum_{q=1}^{\infty}\left[X_{p q}(x) Y_{p q}(y)\right]\left(\left[\frac{P_{z}(x, y, t)}{\rho h Q_{p q}} \int_{x=0}^{a} X_{p q}(x) d x \int_{y=0}^{b} Y_{p q}(y) d y\left(\frac{e^{-\xi \omega_{p q} t}}{\omega_{D}} \sin \left(\omega_{D}(t-\tau) d \tau\right]\right)\right.\right.
\end{aligned}
$$

\section{Fungsi Beban Ledakan Friedlander}

Pada penelitian ini digunakan beban vertikal yaitu beban ledakan setempat Friedlander. Beban ledakan dibagi menjadi 2 fase yaitu fase positif dan fase negatif.

Beban setempat ledakan, $P(x, y, t)$ yang dapat bekerja pada posisi tertentu dapat dinyatakan dengan persamaan sebagai berikut:

$$
\begin{aligned}
& P(t)=28906\left(1-\frac{t}{0.0018}\right) e^{-0.35 \frac{t}{0.0018}} \delta[x-x(t)] \delta[y-y(t)], t \leq 0.0018 s \\
& P(t)=-7226.5\left(\frac{67.5(t-0.0018)}{0.0036}\right)\left(1-\frac{t-0.0018}{0.0036}\right)^{2} \delta[x-x(t)] \delta[y-y(t)],
\end{aligned}
$$

Parameter-parameter yang digunakan mengikuti besaran yang digunakan oleh Susler et. al (2012). Parameter-parameter yang diadopsi dalam penelitian ini dirangkum dalam Tabel 1

Tabel 1 Parameter-parameter beban ledakan Friedlander

\begin{tabular}{|c|c|c|c|}
\hline Notasi & Besaran & Satuan & Keterangan \\
\hline $\mathrm{Z}$ & 6.03 & $\mathrm{~m} / \mathrm{kg}^{(1 / 3)}$ & Scalling laws \\
\hline $\mathrm{W}$ & 100 & $\mathrm{~kg}$ & Massa dari bahan peledak \\
\hline $\mathrm{P}_{\max }$ & 28906 & Newton (N) & Amplitudo fase positif \\
\hline $\mathrm{P}_{\min }$ & 7226.5 & Newton $(\mathrm{N})$ & Amplitudo fase negatif \\
\hline $\mathrm{t}_{\mathrm{A}}$ & 0 & Detik $(\mathrm{S})$ & Waktu awal beban \\
\hline $\mathrm{t}_{\mathrm{P}}$ & 0.0018 & Detik $(\mathrm{S})$ & Durasi fase positif \\
\hline $\mathrm{t}_{\mathrm{N}}$ & 0.0036 & Detik $(\mathrm{S})$ & Durasi fase negatif \\
\hline$\alpha$ & 0.35 & - & Koefisein bentuk gelombang \\
\hline
\end{tabular}

\section{ANALISIS DAN HASIL PENELITIAN}

Objek penelitian ini adalah pelat lantai dengan material beton yang memiliki ketebalan $20 \mathrm{~cm}$. Pelat ini akan dibebani dengan beban in-plane dan beban ledakan Friedlander. Boundary condition pada penelitian ini adalah jepit di keempat sisinya dimana lendutan yang terjadi ada 0 pada perletakannya, selain itu putaran sudut yang terjadi adalah 0 . Nilai k yang di pakai dalam model harus dapat menghasilkan akar-akar (auxiliary p \& q) yang riil. Selain itu, nilai k yang dipilih harus memberi hasil yang rasional, yang artinya tidak memberi hasil lendutan yang berlebihan atau tidak masuk akal. Pelat yang akan ditelitik berada di atas pondasi Pasternak dimana memiliki dua buah lapisan yaitu lapisan pegas dan lapisan geser. 
Tabel 2 Parameter Geometri dan Material Pelat

\begin{tabular}{|l|c|c|}
\hline \multicolumn{2}{|c|}{ Model Pelat } & \multirow{2}{*}{ Pemodelan } \\
\hline Notasi & Parameter [satuan] & \\
\hline a & Panjang pelat [m] & 6 \\
\hline $\mathrm{b}$ & Lebar pelat $[\mathrm{m}]$ & 4 \\
\hline $\mathrm{h}$ & Tebal pelat $[\mathrm{m}]$ & 0.2 \\
\hline$\rho$ & Massa jenis $\left[\mathrm{kg} / \mathrm{m}^{3}\right]$ & 2400 \\
\hline EcX & Modulus elastisitas arah X [MPa] & 25742.9602 \\
\hline Ecy & Modulus elastisitas arah Y [MPa] & 23500 \\
\hline vx & Poisson Ratio arah X & 0.18 \\
\hline vy & Poisson Ratio arahy & 0.15 \\
\hline$\xi$ & Koefisien Redaman [\%] & 0.05 \\
\hline Gs & Koefisien lapisan geser & $2.596 \times 10^{\wedge} 7$ \\
\hline $\mathrm{kf}$ & Koefisien lapisan pegas & $1.662 \times 10^{\wedge} 7$ \\
\hline$\alpha$ & Rasio beban in-plane Ny & 1 \\
\hline
\end{tabular}

\section{Pengaruh Aspek Rasio Pelat terhadap Beban Tekuk Kritis}

Penelitian dilakukan untuk mengetahui rasio pelat terhadap beban tekuk kritis yang dapat diterima oleh pelat. Rasio pelat (c) merupakan perbandingan antara panjang pelat (a) dan lebar pelat (b) yang divariasikan untuk $0,2 \leq \mathrm{c} \leq 4$. Beban kritis yang dihasilkan merupakan hasil perhitungan tanpa adanya pengaruh dari beban transversal. Hasil perhitungan dapat dilihat pada

Gambar 1

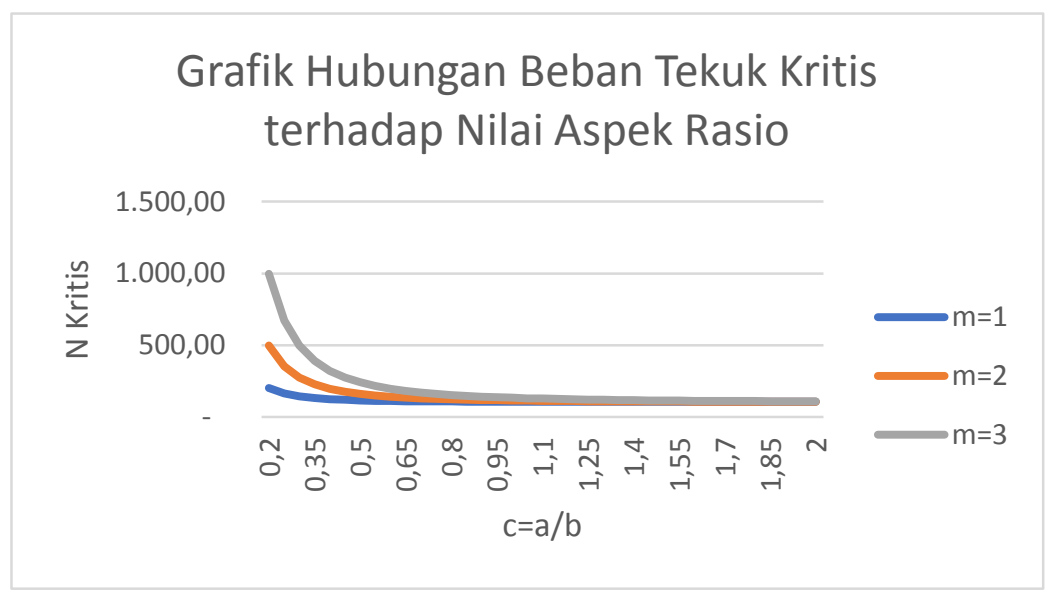

Gambar 1 Grafik Hubungan Beban Tekuk Kritis terhadap Nilai Aspek Rasio

\section{Pengaruh Koefisien Pegas dan Koefisien Geser Terhadap Beban Tekuk Kritis}

Penelitian dilakukan untuk mengetahui pengaruh koefisien pegas pondasi Pasternak (kf) terhadap besarnya beban tekuk kritis yang dapat diterima pelat. Koefisien pegas pondasi Pasternak (kf) yang digunakan adalah 1.662E6, 1.662E7, 1.662E8. Variabel lain tetap digunakan seperti Tabel 1. Beban kritis yang didapat merupakan hasil perhitungan tanpa adanya pengaruh dari beban transversal. 
Gambar 2 menunjukkan semakin besar koefisien pegas maka beban kritis yang didapatkan juga semakin besar yaitu $1.316 \mathrm{E}+08 \mathrm{~N}$.

Gambar 3 menunjukkan semakin besar nilai Gs juga beban kritis yang didapatkan semakin besar yaitu $3.23 \mathrm{E}+08 \mathrm{~N}$. Oleh karena itu koefisien lapisan pegas dan lapisan geser sangat mempengaruhi beban tekuk kritis yang terjadi pada pelat.

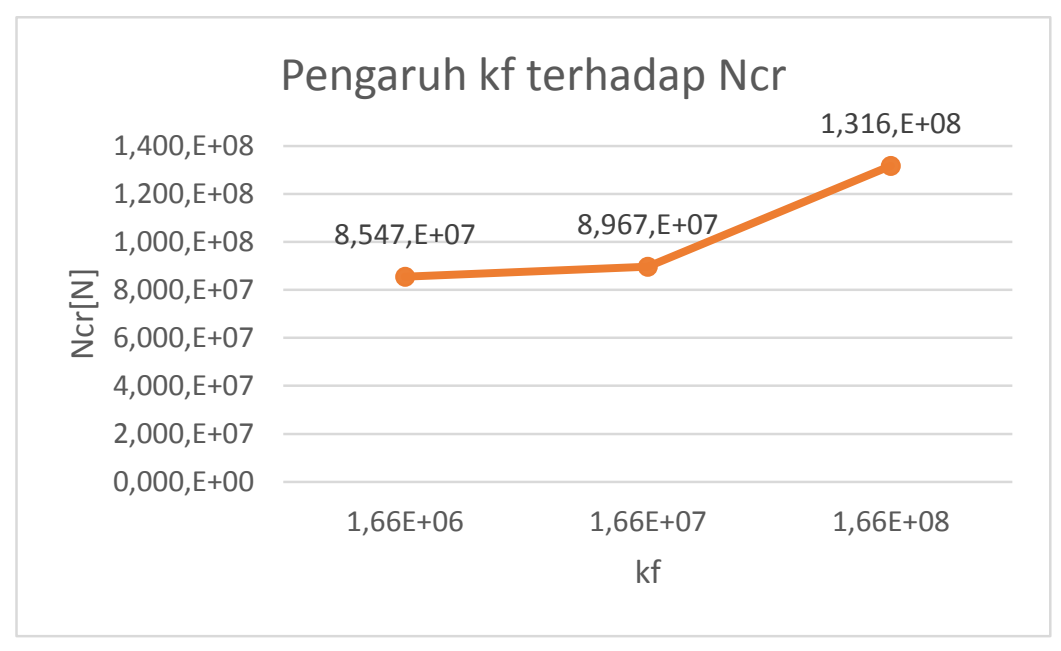

Gambar 2 Pengaruh kf Terhadap N0

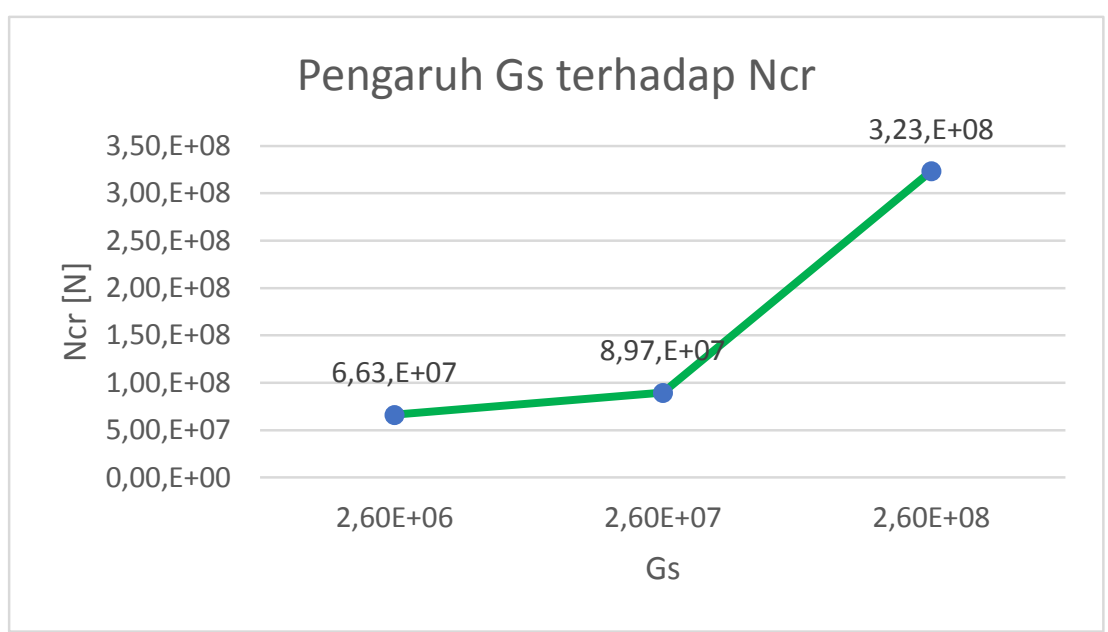

Gambar 3 Pengaruh Gs Terhadap N0

\section{Pengaruh Besar Beban Kritis Terhadap Defleksi Pelat}

Penelitian pada pelat dilakukan dengan menggunakan beban in-plane, untuk itu perlu diteliti terlebih dahulu besaran beban kritis yang dapat diterima oleh pelat. Parameter pelat yang digunakan sama dengan Tabel 1. Beban N0 kritis dipengaruhi oleh nilai koefisien pegas $\left(\mathrm{k}_{\mathrm{f}}\right)$ dan koefisien geser $\left(\mathrm{G}_{\mathrm{s}}\right)$ pada pondasi Pasternak. Berdasarkan nilai $\mathrm{k}_{\mathrm{f}}$ dan $\mathrm{G}_{\mathrm{s}}$ yang digunakan pada Tabel 1 maka didapatkan besaran beban kritis N0 adalah 8.96678E+07 N, dari besar beban kritis 
tersebut maka akan diteliti berapa presentase beban yang dapat diterima oleh pelat tersebut. Pada model ini diteliti dengan 2 jenis beban yaitu beban tarik dan beban tekan pada kedua arahnya.

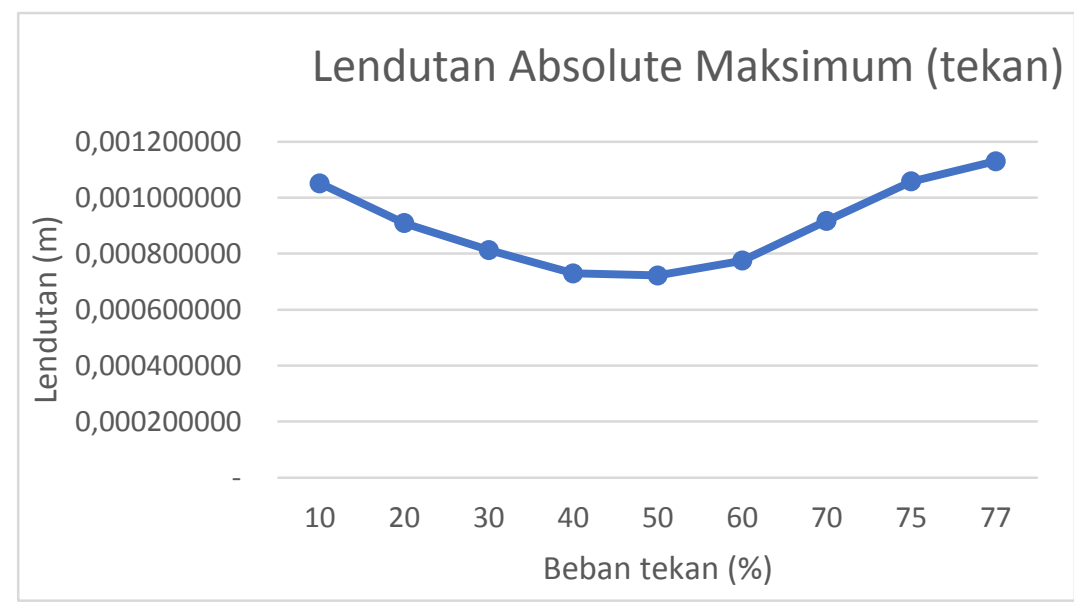

Gambar 4 Riwayat Waktu Defleksi Akibat Beban Tekan Kritis

Setelah dilakukan penelitian diketahui bahwa lendutan akibat beban kritis adalah sebesar 0,011299 m. Beban kritis yang digunakan dinaikan secara perlahan hingga pelat mengalami tekuk yaitu pada $77 \%$. Setelah mencapai batas beban kritis pada program maka hasil frekuensi alami yang terjadi adalah imajiner. Selain beban tekan, pelat juga diteliti dengan memberikan beban tarik pada kedua arahnya. Lendutan yang terjadi dapat dilihat pada Gambar 5 dan

Gambar 6. Defleksi maksimum yang terjadi adalah sebesar $0,003573 \mathrm{~m}$ akibat beban tarik maksimum.

\section{Gambar 5 Riwayat Waktu Lendutan Akibat Beban Tarik \\ Gambar 6 Riwayat Waktu Defleksi Akibat Beban Tarik}

\section{Pengaruh Koefisien Pegas Pondasi Pasternak Terhadap Defleksi Pelat}

Pelat diteliti dengan beberapa kondisi tanah yang digambarkan dengan koefisien pegas pada pondasi Pasternak. Koefisien pegas yang digunakan yaitu berdasarkan penelitian yang dilakukan Gibigaye pada tahun 2015. Semakin kecilnya nilai koefisien pegas menandakan bahwa semakin kerasnya tanah. Gambar 7 menunjukkan perbandingan lendutan yang terjadi dengan variasi koefisen pegas. Koefisen pegas $\left(\mathrm{k}_{\mathrm{f}}\right) 1.662 \mathrm{E}+08$ menunjukkan lendutan paling kecil terjadi pada pelat yaitu sebesar $0,00073 \mathrm{~m}$, sedangkan dengan koefisen pegas $\left(\mathrm{k}_{\mathrm{f}}\right) 1.662 \mathrm{E}+06$ menunjukkan lendutan paling besar yaitu $0,00115 \mathrm{~m}$.

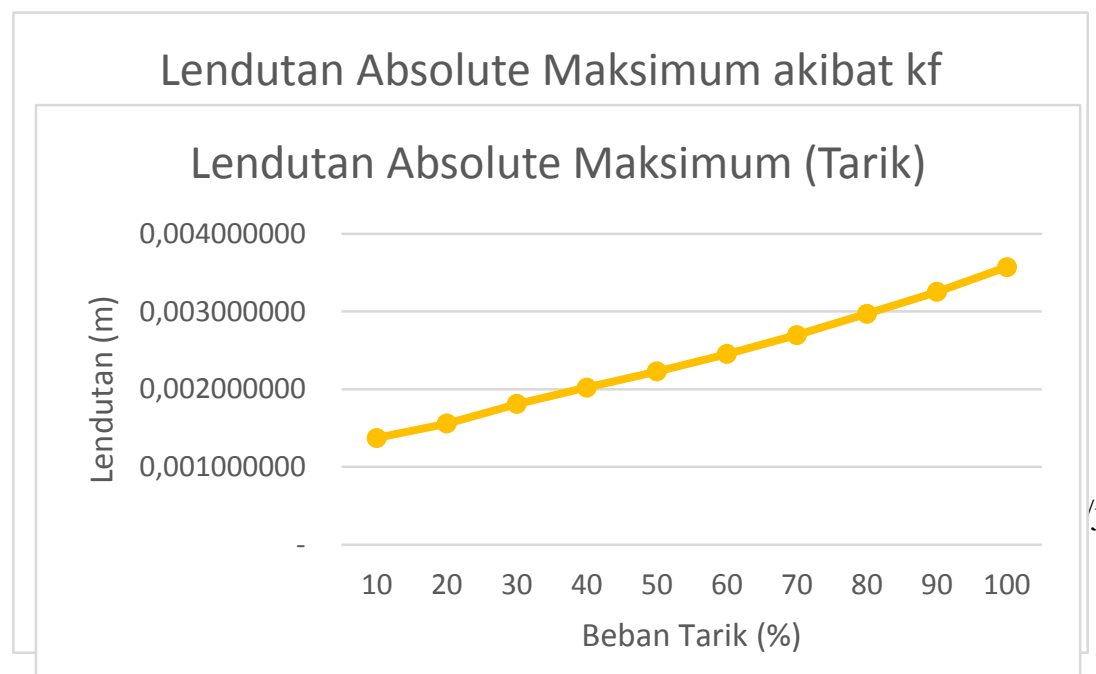




\section{Gambar 7 Lendutan Maksimum Akibat Koefisien Pegas}

\section{Pengaruh Posisi Beban Transversal Terhadap Respons Dinamik Pelat}

Penelitian ini dilakukan untuk memperoleh pengaruh posisi beban transversal terhadap respons dinamik dari pelat. Dalam penelitian ini, beban transversal diambil pada posisi y tetap pada $\mathrm{y}=\mathrm{b} / 2$ dengan posisi $\mathrm{x}$ yang bervariasi pada $\mathrm{x}=1 / 8 \mathrm{a} ; 2 / 8 \mathrm{a} ; 3 / 8 \mathrm{a}, 0,5 \mathrm{a}$ (a merupakan panjang pelat). Beban transversal yang digunakan berdasarkan beban setempat Friedlander. Gambar 8 menunjukkan bahwa semakin beban menjauhi perletakan maka lendutan yang terjadi semakin besar. Lendutan terbesar terjadi pada $4 / 8$ a atau tengah bentang yaitu $0,00105 \mathrm{~m}$.

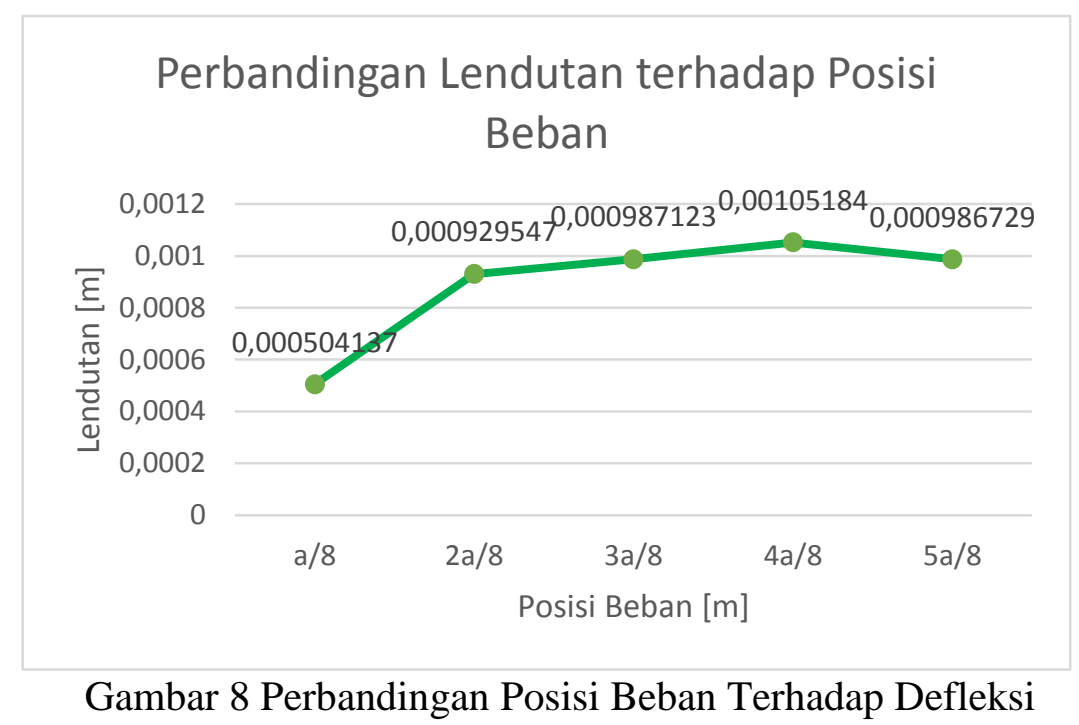

\section{Pengaruh Ketebalan Tanah Terhadap Respon Dinamik Pelat}

Gambar 9 menunjukkan variasi lendutan pada tengah pelat $(\mathrm{a}=3 \mathrm{~m} ; \mathrm{b}=2 \mathrm{~m})$ berdasarkan parameter pada Tabel 1. Lendutan yang terjadi pada variasi kedalaman tanah yaitu $0,5 \mathrm{~m}, 2,5 \mathrm{~m}$, dan 7,5 m. Lendutan maksimum yang terjadi pada kedalaman $\left(\mathrm{H}_{\mathrm{s}}\right) 7,5 \mathrm{~m}$ adalah $0,00129 \mathrm{~m}$, sedangkan pada kedalaman $\left(\mathrm{H}_{\mathrm{s}}\right)$ 2,5 $\mathrm{m}$ adalah $0,00074 \mathrm{~mm}$, dan pada kedalaman $\left(\mathrm{H}_{\mathrm{s}}\right)$ 2,5 $\mathrm{m}$ adalah $0,00055 \mathrm{~mm}$. Gambar 9 menunjukan lendutan maksimum yang terjadi pada setiap kedalaman yang diteliti, dapat dilihat bahwa semakin dalam tanah yang ditinjau maka semakin kecil nilai lendutan yang terjadi. 


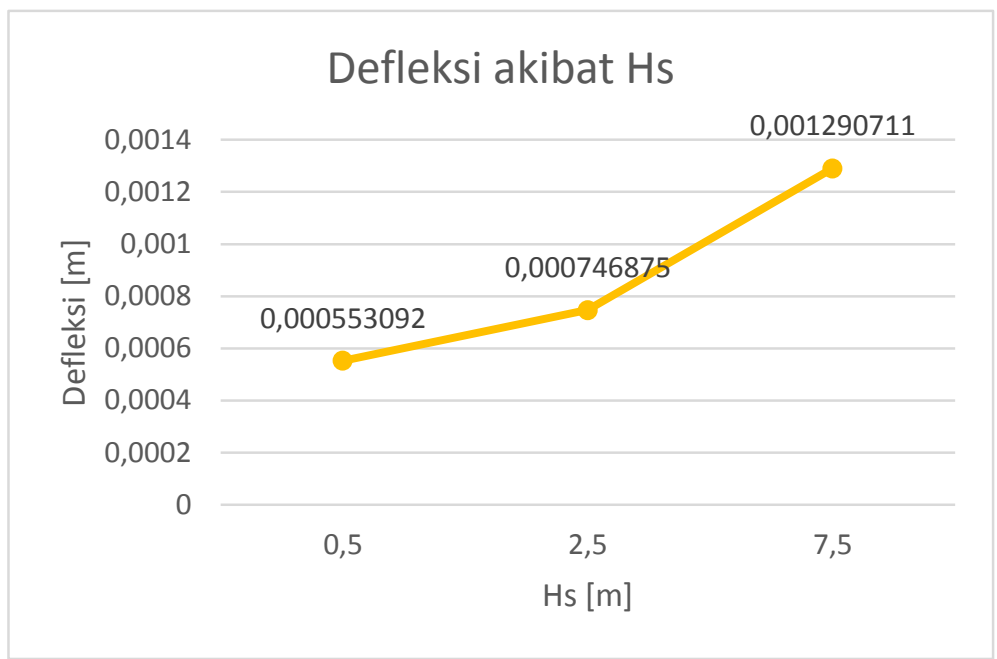

Gambar 9 Perbandingan Lendutan dengan Variasi Kedalaman Tanah $\left(\mathrm{H}_{\mathrm{s}}\right)$

\section{Pengaruh Durasi Beban Ledakan Friedlander Terhadap Respons Dinamik Pelat}

Penelitian ini dilakukan untuk mengetahui pengaruh variasi durasi ledakan pada fase positif terhadap respons pelat yang terjadi. Durasi beban ledakan yaitu 0,0016 s yang didasarkan pada penelitian Susler (2012). Variasi durasi ledakan yang digunakan yaitu 0,001 s, 0,0016 s dan $0,002 \mathrm{~s}$. Lendutan saat durasi beban ledakan 0,001 adalah sebesar 0,00061 m, sedangkan pada durasi beban ledakan $0,0016 \mathrm{~s}$ lendutan yang terjadi sebesar $0,00105 \mathrm{~m}$, dan pada durasi $0,002 \mathrm{~s}$ lendutan yang terjadi sebesar $0,00117 \mathrm{~m}$. Pada Gambar 10 dapat dilihat bahwa semakin panjang durasi beban maka lendutan yang terjadi pada pelat semakin besar.

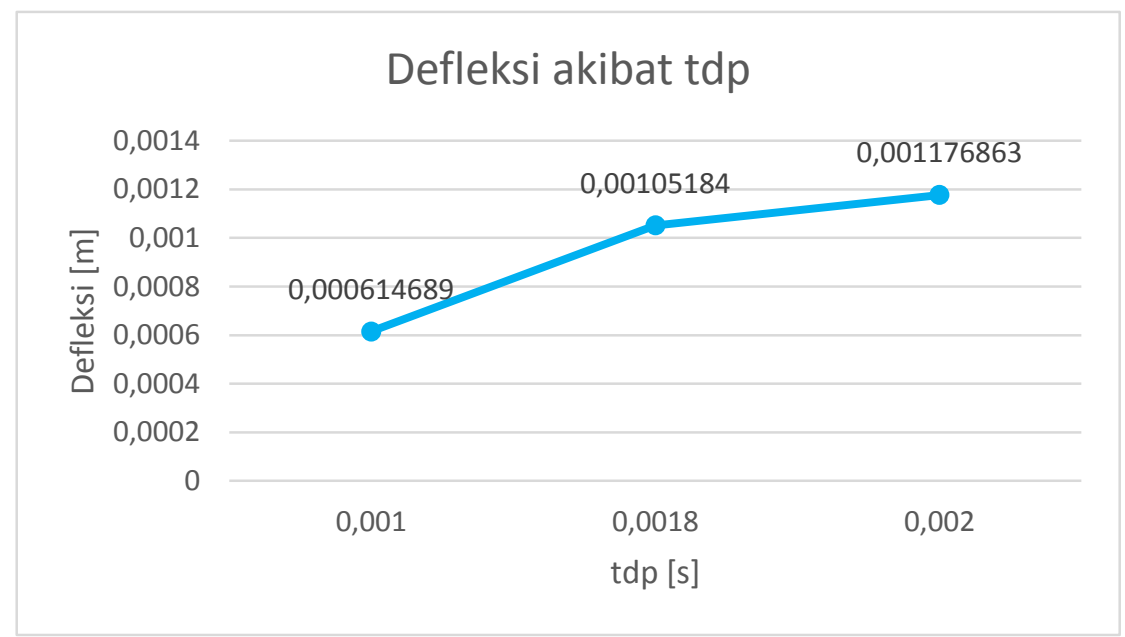

Gambar 10 Lendutan Akibat Variasi Durasi Fase Positif

\section{Pengaruh Tebal Pelat terhadap Respons Dinamik Pelat}

Tebal pelat menjadi salah satu parameter yang mempengaruhi lendutan pada pelat. Pada penelitian ini digunakan 3 variasi tebal pelat yaitu $20 \mathrm{~cm}, 25 \mathrm{~cm}$, dan $30 \mathrm{~cm}$. Berdasarkan parameter yang digunakan pada Tabel 1 dengan tebal pelat $20 \mathrm{~cm}$ didapatkan lendutan yang terjadi pada pelat yaitu $0,00097 \mathrm{~m}$, kemudian dengan tebal pelat $25 \mathrm{~cm}$ lendutan yang terjadi yaitu $0,00064 \mathrm{~m}$, dan dengan tebal pelat $30 \mathrm{~cm}$ lendutan yang terjadi yaitu $0,000403 \mathrm{~m}$. Pada Gambar 11 dapat dilihat perbandingan lendutan yang terjadi akibat perbedaan ketebalan pelat dimana semakin tebal suatu pelat maka lendutan yang terjadi semakin kecil. 


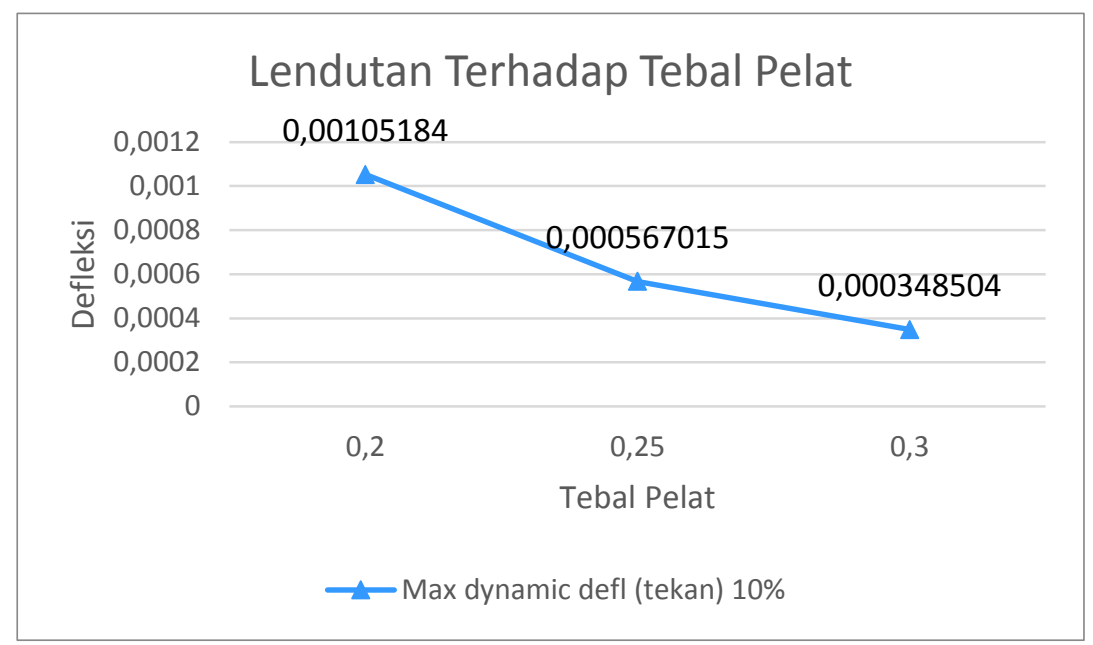

Gambar 11 Perbandingan Lendutan terhadap Tebal Pelat

\section{Pemeriksaan Syarat Lendutan Kecil}

Lendutan maksimum yang terjadi yaitu pada kondisi beban tekan yaitu sebesar $11.3 \mathrm{~mm}$, sedangkan lendutan ijin untuk kategori lendutan kecil adalah:

$$
\delta_{\text {all }}=\frac{h}{10}=\frac{200}{10}=20 \mathrm{~mm}
$$

Lendutan maksimum absolut yang terjadi lebih kecil dibandingkan dengan lendutan ijin (11.3 $\mathrm{mm}<<20 \mathrm{~mm}$ ) sehingga hasil analisis dapat dikatakan valid.

\section{KESIMPULAN}

Penelitian dilakukan pada pelat orthotropik dengan perletakan jepit di atas pondasi Pasternak dengan beban ledakan Friedlander dan beban in-plane. Terdapat banyak faktor yang dapat mempengaruhi respons dinamik pelat. Beban kritis terendah terjadi pada ragam getar pertama baik dalam arah $\mathrm{x}$ dan arah $\mathrm{y}(\mathrm{m}=1, \mathrm{n}=1)$. Semakin besar aspek rasio pelat maka semakin besar beban tekuk kritis yang dapat diterima pelat. Koefisien pegas dan geser pondasi Pasternak akan mempengaruhi beban kritis yang terjadi. Semakin besar nilai koefisien pegas dan koefisien geser maka beban in-plane yang terjadi juga semakin besar, dengan begitu lendutan maksimum yang terjadi juga semakin besar. Lendutan maksimum akibat beban kritis tekan adalah sebesar $77 \%$ yaitu sebesar 0,011299 m, sedangkan untuk beban tarik dapat mencapai hingga $100 \%$ dengan lendutan sebesar 0,003573 m. Untuk koefisien pegas lapisan Pasternak dengan nilai 1.662E+08 defleksi maksimum yang terjadi adalah $0,00073 \mathrm{~m}$, sedangkan untuk koefisien pegas lapisan Pasternak 1.6662E+07 defleksi maksimumnya adalah 0,00105 m, dan untuk koefisien pegas lapisan Pasternak 1.662E+06 defleksi maksimum yang terjadi adalah 0,00115 m.

Posisi beban memiliki pengaruh terhadap defleksi yang terjadi. Semakin dekat posisi beban dengan tumpuan maka semakin kecil defleksi maksimum yang terjadi. Pemodelan beban ledakan dengan beban yang berada di seperdelapan bentang memiliki defleksi sebesar 0,000504 $\mathrm{m}$, beban ledakan pada posisi seperempat memilik defleksi sebesar 0,000929, beban ledakan pada posisi tiga per delapan bentang memiliki defleksi 0,000987 dan posisi beban ledakan pada setengah bentang memiliki nilai defleksi terbesar yaitu $0,00105 \mathrm{~m}$

Selain posisi beban, kedalaman tanah juga mempengaruhi respons dinamik pelat. Semakin tebal lapisan tanah yang ikut bereaksi dalam menahan beban dinamik maka semakin besar lendutan 
maksimum yang terjadi. Durasi beban ledakan akan mempengaruhi defleksi maksimum yang terjadi pada pelat. Semakin lama durasi fase positif beban ledakan setempat Friedlander maka semakin besar defleksi maksimum yang terjadi. Ketebalan pelat yang dianalisa dengan beban yang sama akan memiliki lendutan yang berbeda. Tebal pelat $20 \mathrm{~cm}$ memberikan hasil lendutan yaitu $0,00105 \mathrm{~m}$, sedangkan tebal pelat $25 \mathrm{~cm}$ memiliki lendutan yaitu $0,00056 \mathrm{~m}$, dan pelat dengan tebal $30 \mathrm{~cm}$ memiliki lendutan yaitu $0,00034 \mathrm{~m}$ sehingga dapat disimpulakan semakin tebal pelat maka lendutan yang terjadi semakin kecil.

\section{REFERENSI}

Gibigaye, M, et al. (2015). Dynamic Response of a Rigid Pavement Plate Based on an Inertia Soil. International Scholarly Research Notices, 2016(1), 1-9.

Moon, N. N. (2009). Prediction of Blast Loading and Its Impact on Buildings. National Institute of Technology.

Ngo, T., Mendis, P., Gupta, A., \& Ramsay, J. (2007). Blast Loading and Blast Effects on Structures - An Overview. Electronic Journal of Structural Engineering, EJSE Special Issue: Loading on Structure, 7, 76-91.

Susler, et.al. (2012). The Nonlinear Dynamic Behavior of Tapered Laminated Plates Subjected to Blast Loading. Shock and Vibration, 19(6).

Szilard, R. (1974). Theory and Analysis of Plates: Classical and Numerical Methods. Prentice Hall, Inc., New Jersey.

Szilard, R. (2004). Theories and Applications of Plate Analysis: Classical, Numerical, and Engineering Method's. John Wiley \& Sons, Inc., New Jersey.

Timoshenko, S. (1955). Strength of materials, part I Elementary Theory and Problems. Robert E. Krieger Publishing Company, Huntington, New York. 